\title{
EFFECT OF GROUND COVER AND PASTURE HEIGHT ON OVIPOSITION AND ESTABLISHMENT OF SOLDIER FLY LARVAE
}

\author{
W. M. KAIN and G. BURTON \\ Soil and Field Research Organisation, \\ Ruakura Agricultural Research Centre, MAF, Hamilton
}

Summary

\begin{abstract}
Populations of the Australian soldier fly (Inopus rubriceps) are extremely sensitive to changes in ground cover over both the spring and autumn oviposition periods. This stems from the female's reluctance to oviposit in short, open pastures and is reflected in fewer and smaller egg clusters. Ground cover was also found to influence egg viability. Chemical fallowing over a three month period caused an $83 \%$ and $98 \%$ reduction in larvae of the previous and current generations respectively. Observations of hay and silage paddocks suggest that these management practices have application for controlling soldier fly, as does the manipulation of grazing intensity and frequency over the insect's oviposition period.
\end{abstract}

\section{INTRODUCTION}

The life cycle of the Australian soldier fly (Inopus rubriceps) has been reviewed by Wilcocks (1971). He noted that although adults emerge over a long time, emergence has two well defined peaks, one in autumn (late March to late April), the other in spring (mid November to mid December). Adults live for only a few days and lay their eggs at shallow depths (Campbell and Koehler 1971) or in cracks in the soil, under vegetation and at the plant crown-soil interface. Eggs hatch within two weeks but if subjected in the laboratory to ambient humidity shrivel and die (Campbell and Koehler 1971; Wilcocks 1971).

The length of larval life is variable but the average period is thought to be approximately 23 months (Wilcocks 1973). Pupae appear in the soil one month prior to adult emergence and female flight seems to be localised within the paddock of origin (Wilcocks 1971).

The purpose of this paper is to report on studies conducted at Ruakura over the autumn and spring of 1974 to assess the sensitivity of soldier fly to ground cover and pasture height during adult emergence, oviposition and the establishment of young larvae in the soil.

\section{EXPERIMENTAL}

Autumn pasture height trial

The three pasture heights chosen for study in this trial were short $(1.5$ to $4 \mathrm{~cm})$, medium $(7.5$ to $12.5 \mathrm{~cm}$ ) and long (uncut). The height in the latter treatment ranged between $13 \mathrm{~cm}$ and $20 \mathrm{~cm}$. The short and medium treatments were maintained by mowing. Plots were inspected and mown if necessary at least twice a week from early February until after the autumn flight season. The trial consisted of 15 plots $3 \times 2 \mathrm{~m}$ Proc. 28th N.Z. Weed and Pest Control Conf. 
laid out in five randomised blocks with one replicate per block. Plots from the medium and long treatments were divided in half longitudinally, one half was defoliated to a height of between 1.5 and $2.5 \mathrm{~cm}$ in late April after the major autumn flights had occurred, while the other half was maintained in its former state.

\section{Spring pasture height trial}

The six treatments included in this experiment were short, long, defoliated (at three different times) and chemically killed pasture. The short and long pasture treatments have been described. With the exception of the defoliation treatments all treatments were imposed two weeks before spring emergence and maintained throughout the flight season. The defoliation treatments were imposed by cutting long pasture at a height of 1.5 to $2.5 \mathrm{~cm}$ at one of three times: at the beginning of the emergence period, at peak emergence or at the end of the emergence period. After defoliation plots were maintained as short pasture. Vegetation on the chemically bared plots was removed by high rates of paraquat.

The trial consisted of 30 plots $3 \times 3.5 \mathrm{~m}$ arranged in five single replicate blocks. Each plot was split longitudinally in half. One half was enclosed by an insect proof cage, $1.2 \times 2.4 \mathrm{~m}$ and $1.2 \mathrm{~m}$ high to prevent adult dispersal. The sub-plots and plots were divided by a $1 \mathrm{~m}$ wide buffer strip which was maintained as short pasture.

Sampling was carried out approximately three months after flight had ceased so that small larvae arising from eggs of the current generation could be accurately extracted and identified. Nine $2.5 \mathrm{~cm}$ diameter cores were taken to a depth of $20 \mathrm{~cm}$ from each quarter of each plot and bulked. A wet sieving-flotation extraction method developed for soldier fly by Wilcocks and Oliver (1971) was used. Larvae were divided into three classes: very large (close to the size of pupae), those easily seen by the naked eye and small larvae which could only be identified under magnification (x5). It was assumed largely from Wilcocks' (1973) studies that the majority of small larvae arose from eggs laid by adults during the most recent flight season.

\section{Oviposition studies}

Three in copula pairs of soldier flies were collected in the field and placed under $7.5 \mathrm{~cm}$ diameter $\times 20 \mathrm{~cm}$ mesh cages on each of the autumn and spring treatments. A minimum of 13 cages was placed on each treatment.

After 24 hours, by which time the female had usually oviposited and/or died, the cages and caged areas were removed and the number of clusters and, in spring, the number of eggs, recorded. Viability was assessed by incubating eggs at $25^{\circ} \mathrm{C}$ on agar in petrie dishes.

Adult emergence was monitored from emergence cages, of the type developed by Oliver (pers. comm.), placed on grazed pasture adjacent to the trial sites. Cages were inspected weekly until the beginning of the emergence period and every two days thereafter.

Prior to statistical analyses all data were transformed to a square root base. The mean densities given in all tables are calculated from the raw data.

\section{RESULTS}

The effect of pasture height and ground cover, during or close to the emergence period, on subsequent larval populations of soldier fly measured three months after flight are given in Tables 1 and 2 . 
TABLE 1: EFFECT OF PASTURE HEIGHT DURING THE AUTUMN EMERGENCE AND OVIPOSITION PERIOD OF SOLDIER FLY ON THE SUBSEQUENT GENERATION OF SMALL LARVAE

\begin{tabular}{lcr}
\hline Treatments & $\begin{array}{c}\text { No. of small larvae } \\
0.1 \mathrm{~m}^{2} \\
\text { Defoliated } \dagger\end{array}$ \\
\hline Short $(1.5-4.0 \mathrm{~cm})$ & $150 \mathrm{bB}$ & \\
Medium $(7.5-12.5 \mathrm{~cm})$ & $1570 \mathrm{aA}$ & $790 \mathrm{aAbB}$ \\
Long $\quad$ (uncut) & $2060 \mathrm{aA}$ & $1040 \mathrm{aAbB}$ \\
\hline
\end{tabular}

* imposed prior to emergence

$\dagger$ imposed after peak emergence

TABLE 2: EFFECT OF GROUND COVER AND PASTURE HEIGHT OVER THE SPRING OVIPOSITION PERIOD ON LARVAL DENSITY OF SOLDIER FLY IN CAGED AND UNCAGED PLOTS

\begin{tabular}{|c|c|c|c|c|c|c|}
\hline \multirow{2}{*}{$\begin{array}{l}\text { Treatment } \\
\text { Pasture height or cover } \\
\quad \text { Time of treatment }\end{array}$} & \multicolumn{6}{|c|}{ No. larvae $/ 0.1 \mathrm{~m}^{2}$} \\
\hline & \multicolumn{3}{|c|}{$\begin{array}{l}\text { Older larvae } \dagger \\
\text { ed Uncaged Mean }\end{array}$} & $\begin{array}{r}S \gamma \\
\text { Caged }\end{array}$ & $\begin{array}{l}\text { Uall larv } \\
\text { Uncage }\end{array}$ & $\begin{array}{l}\text { let† } \\
\text { Mean }\end{array}$ \\
\hline \multicolumn{7}{|l|}{ Defoliation } \\
\hline Beginning of Emergence & 196 & 161 & $178 \mathrm{aA}$ & 26 & 6 & $16 \mathrm{bB}$ \\
\hline Peak Emergence & 180 & 173 & $176 \mathrm{aA}$ & 35 & 21 & $28 \mathrm{bB}$ \\
\hline End of Emergence & 206 & 204 & $204 \mathrm{aA}$ & 34 & 32 & $33 \mathrm{bB}$ \\
\hline \multicolumn{7}{|l|}{ Chemically Bared } \\
\hline Prior to Emergence & 43 & 32 & $37 \mathrm{bB}$ & 1 & 5 & $3^{*}$ \\
\hline \multicolumn{7}{|l|}{ Short } \\
\hline Prior to Emergence & 180 & 157 & $169 \mathrm{aA}$ & 27 & 16 & $21 \mathrm{bB}$ \\
\hline \multicolumn{7}{|l|}{ Long } \\
\hline Prior to Emergence & 261 & 195 & $228 \mathrm{aA}$ & 217 & 181 & 199 aA \\
\hline
\end{tabular}

* Not included in analyses as numbers were too small

$\dagger \quad$ Larvae from eggs laid prior to spring 1974

†† Larvae from eggs laid in spring 1974

Plots maintained in medium and long pasture harboured approximately 10 times as many small larvae as plots of short pasture. Severe defoliation of medium and long pasture plots at the end of the autumn flight reduced small larvae by $50 \%$. Similar treatments imposed in spring at the beginning, at the peak and at the end of emergence reduced small larvae by more than $80 \%$ in comparison with long pasture. Although small differences were apparent between times of defoliation these were not significant. Pasture height did not significantly affect the density of older larvae but chemically bared ground supported $98 \%$ and $83 \%$ less small and older larvae, respectively, than long pasture.

The marked depression in small larvae under the short pasture does not appear to be associated with female dispersal from unfavourable to favourable oviposition sites, as shown by the small but insignificant differences between caged and uncaged subplots (Table 2). Oviposition studies showed that gravid females placed on short, open pasture (i.e. the defoliated and short pasture treatments) laid fewer egg clusters than their counterparts on the long and medium pasture treatments (Table 3). Cluster size was also reduced on the pasture defoliated in spring. Egg viability was reduced on the treatments which had an adverse effect on the numbers and size of egg clusters (Table 3). 
TABLE 3: NUMBER OF EGGS AND EGG CLUSTERS LAID BY CAGED SOLDIER FLY IN PASTURE CUT TO DIFFERENT HEIGHTS AND CHEMICALLY BARED

\begin{tabular}{|c|c|c|c|c|}
\hline Treatments & $\begin{array}{l}{ }^{*} \text { Mean cluster } \\
\text { No. (autumn) }\end{array}$ & $\begin{array}{l}{ }^{*} \text { Mean cluster } \\
\text { No. (spring) }\end{array}$ & $\begin{array}{c}\text { Mean cluster } \\
\text { size (spring) }\end{array}$ & \% Unhatched \\
\hline Defoliated & & $0.46 \mathrm{cB}$ & $38 \mathrm{bB}$ & 32 \\
\hline $\begin{array}{l}\text { Maintained } \\
\text { Medium }\end{array}$ & $\begin{array}{l}1.57 \mathrm{bB} \\
3.21 \mathrm{aA}\end{array}$ & $0.84 \mathrm{bAB}$ & $77 \mathrm{aA}$ & 15 \\
\hline $\begin{array}{l}\text { Long } \\
\text { Chemically Bared }\end{array}$ & $3.93 \mathrm{aA}$ & $\begin{array}{l}1.23 \mathrm{aA} \\
0.0 .8 * *\end{array}$ & $\begin{array}{l}71 \text { aA } \\
33 * *\end{array}$ & $\begin{array}{l}11 \\
57\end{array}$ \\
\hline
\end{tabular}

* per three flies

** one observation

\section{DISCUSSION}

At least three factors are involved in the effect of short, open pasture on the subsequent density of small larvae: reductions in the number and size of egg clusters and reduced egg viability. Which factor makes the major contribution will depend on the time that the defoliation treatments are imposed relative to the oviposition period.

Oviposition studies on the short spring pasture treatment revealed a reduction of approximately $30 \%$ in the number of clusters laid but no apparent differences in cluster size or egg viability, compared to long pasture (Table 3 ). However, there was an $89 \%$ reduction in the number of small larvae in the short spring pasture treatment compared to the long pasture (Table 2). This reduction in small larvae may have been partly caused by a higher egg mortality in the short spring pasture. The egg mortalities in Table 3 were assessed after no more than 24 hours exposure to field conditions. No account was taken in these studies of the effects on egg viability of long term exposure to unfavourable environmental conditions and, in the case of the defoliation treatments, the effects of sudden changes in the eggs' environment.

Defoliation after peak emergence appeared to be less effective in reducing the number of small larvae in the autumn than in the spring. Such seasonal differences may arise from differences in temperature and/or moisture at the base of the pasture between March-April and NovemberDecember.

The 10-fold difference between the number of small larvae under long pasture in the autumn trial (Table 1) and the spring trial (Table 2) probably reflects the greater number of females (approximately double) that emerged in the autumn than the spring, the greater number of egg clusters laid by autumn females than spring females (Table 3) and a lower natural mortality in the autumn and winter than in the spring and summer.

The practical importance of these studies is highlighted by observations made on hay, silage and sheep grazed paddocks at Ruakura (Table 4). The silage paddock in late December after adult emergence. The grazed paddock was in a heavily stocked experimental farmlet and was well grazed throughout the spring. Although a higher larval density was found in the silage paddock both the silage and grazed paddock harboured a smaller percentage of young larvae than the hay paddock.

The results of the chemically bared treatment suggest that the success of cultivation in controlling soldier fly may arise from the removal of live plant material which prevents oviposition and induces larval starvation. With the development of direct drilling techniques, a two to three month chemical fallowing would seem to be a less expensive method of soldier fly control than mechanical cultivation. 
TABLE 4: DENSITY OF SOLDIER FLY LARVAE IN PADDOCKS MANAGED IN DIFFERENT WAYS IN THE SPRING

\begin{tabular}{lcccc}
\hline Treatments & $\begin{array}{c}\text { Small larvael } \\
0.1\end{array}$ & $\begin{array}{c}\text { Total larvae/ } \\
\mathrm{m}^{2} \pm \text { S.E. }\end{array}$ & $0.1 \mathrm{~m}^{2} \pm$ S.E. & $\begin{array}{c}\text { \% Small } \\
\text { larvae }\end{array}$ \\
\hline Silage & $36 \pm 13$ & $510 \pm 28$ & 7 \\
Hay & $68 \pm 18$ & $337 \pm 50$ & 20 \\
Grazed & $9 \pm 5$ & $242 \pm 33$ & 4 \\
\hline
\end{tabular}

\section{ACKNOWLEDGEMENTS}

The technical assistance of $\mathrm{Mr} \mathrm{J}$. Meekings and $\mathrm{Mr} \mathrm{T}$. Holland is gratefully acknowledged.

\section{REFERENCES}

Campbell, R. L. and Koehler, C. S., 1971. Biological observations on Inopus rubriceps (Diptera: Stratiomyidae). Ann. Ent. Soc. Amer. 64 (1): 1-11.

Wilcocks, C. R., 1971. Review of the life cycle of the Australian soldier fly. Proc. 24th N.Z. Weed and Pest Control Conf.: 151-154.

Wilcocks, C. R. and Oliver, E. H. A., 1971. A rapid mechanical method for extracting soil arthropods. N.Z. Jl. Ag. Res. 14: 725-734.

Wilcocks, C. R., 1973. Some observations on the population dynamics of Australian soldier fly (Inopus rubriceps (Macquart)) (Diptera: Stratiomyidae). D.Phil. Thesis, Waikato University.

(Chairman's Summary Continued).

are good economic reasons to expand this area of research. It is important to keep this preliminary trial in perspective. Materials which do well in such a well controlled experiment may not achieve the same result under variable soil and seasonal conditions in the field (see Rowe and Mackay's comment on carbofuran seed dressings). The superiority of omethoate and trichlorfon on larval survival is interesting, but care in interpretation should be taken because allowance for differences in percent concentration was not made when applying the insecticidal seed coating. The good result achieved with trichlorfon could possibly be a reflection of its water solubility and its conversion to dichlorvos. Utilization of lime (as reported by French and Pottinger in these proceedings to enhance trichlorfon activity merits further consideration, as does "on farm" insecticidal seed dressing, immediately prior to sowing, in order to minimize some of the problems.

Overall these are four interesting and well presented papers, clearly pointing to the continuing problem of finding a greater choice of much more profitable control strategies for use against soldier fly. They have all indicated the need for extension of applied research, with the two field oriented insecticidal evaluation studies both emphasizing the need to differentiate the effects of insecticides on pests other than the primary target pest (e.g. eelworms affecting pasture production and Argentine stem weevil on maize) and beneficial species such as earthworms. 